\title{
Road Parameter in Conversion or New Settlement Areas
}

\author{
Halil Ibrahim Polat* \\ Yildiz Technical University, Istanbul, Turkey
}

*Corresponding author: Halil Ibrahim Polat, Yildiz Technical University, Istanbul, Turkey.

Received Date: January 30, 2019

Published Date: February 20, 2019

\begin{abstract}
The road is the main instrument of urban thought and urban image. Since the existence of mankind, they have made some practices in order to reach the places they created. Transportation should be the first criterion for building a city. For this reason, the road parameter should be in one of the priority orders in the zoning areas both in the construction of new cities and in the process of urban transformation. There is a long-running process challenging a lot of planning standards for settlements area to be transformed. Urban transformation studies in the world have difficulties in accordance with international planning criteria because of the unlicensed and illegally built high rates in the existing risky areas and the number of the population residing in these areas which is considerably higher than the density value of the approved current plans. From 1950's onwards, planning of urban informal settlements which are heavily populated for various reasons by slum dwellers could find application area due to social and political influences. This situation brought along some social problems. It is seen that parameters such as urban facilities, technical infrastructure and transportation are transformed into secondary issue in the planning studies, mainly due to the high floor area ratio (FAR) and building coverage ratio (BCR) demands by stakeholders. The demand to increase the value of FAR leads directly to increase in population density, thus resulting in the depreciation of social facilities and transport area in existing transformation zone and the deprivation of living facilities in healthy urban areas. In this study, especially in the new places where the transformation application will be carried out, an idea is made about the percentage and amount of road required for planning in accordance with international standards and suggestions are tried to be developed.
\end{abstract}

Keywords: Road; Conversion; Transformation; Urbanization

\section{Introduction}

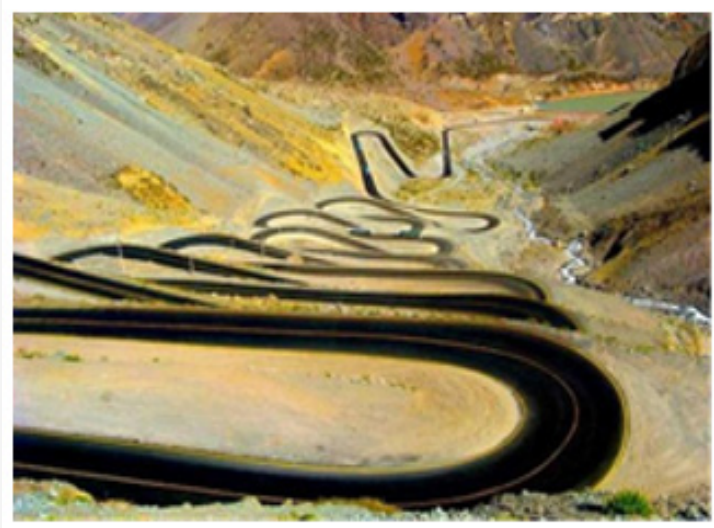

Figure 1: The path of the road [2].
The road is expressed as the distance traveled on land, in the air, in the water to go from place to place [1]. It can be said that it is an image of civilization. The place where the road was taken and the area where it is exceeded can be a measure of height, communication, culture, economy and well-being (Figure 1). It is the main parameter of the so-called urban. Roads to the focal point of the places that humanity has established since the existence of humanity. In this context, a civilization cannot be depicted without a path (Figure 1). The road points to a city. The city also ruled that there are people living there. In this context, when you build a city, you need to specify the routes that will be built in itself. It is no longer difficult to put the road space needed in the new settlements in line with the planning criteria. Because the new settlements are witnessing the moment in which the time is experienced, it can give the exact amount of land required. The main problem is generally 
in the old settlements. One of the biggest problems is the areas to be set off when the need for a possible urban transformation occurs in the regions formed mostly in the amorphous streets and in the buildings that have completed their life cycle (Figure 2). Because, at present, people do not renounce the dimensions of the buildings they are accommodating in and demand more. This issue is one of the main problems especially among the executives and residents during the transformation process [2].

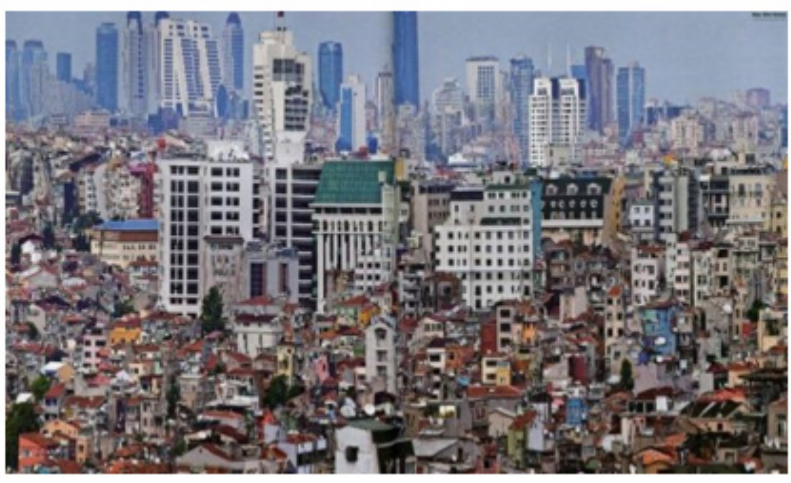

Figure 2: The place where the road goes [3].

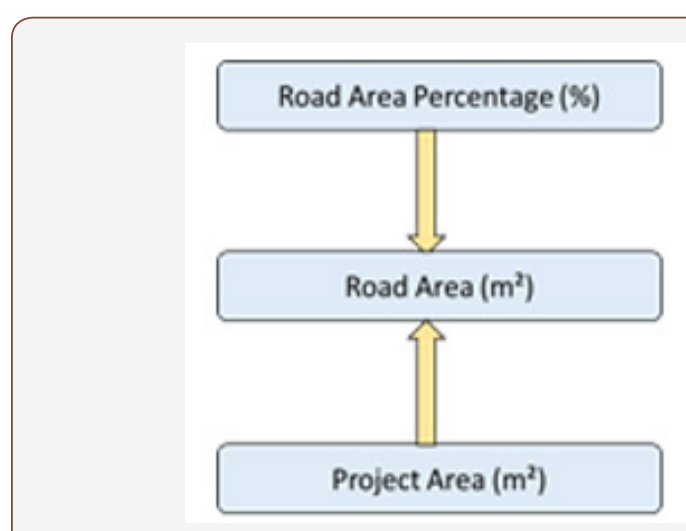

Figure 3: Road area interaction diagram.

For the optimal planning of land use in a region, the relationship between the parameters related to the land should be enabled to make the optimum plan. In this respect, it is thought that benefiting from a mathematical calculation method or project may be a platform for a more efficient planning study. Thus, it is understood that urban planning and design factors play a significant role in the reduction of earthquake damages as well as the formation of urban image. In urban design, it is not possible to produce independent decisions from city planning criteria and urban development plans. Because, the decisions that will be developed unconsciously as the plan decisions in urban design significantly direct the city's local or regional seismic behavior negatively [3]. In this context, one of the main factors of the construction of a qualified city is the correct planning of the transportation network corridors that organize the city. In light of national and international standards and recommendations, this paper allows for a planning study by taking into account the needs of an area for social and physical equipment and allows to measure the effectiveness of the road parameter in combining planning, architectural thinking, engineering parameters, and environmental impacts (Figure 2). In this study, it is aimed to put forward a discussion on what should be the rate of road in a region by considering the international standards in new settlements and urban transformation planned areas. In some cities, where the data can be accessed firstly, the areas allocated for transportation in the land were reached. Methodologically, firstly the rate of areas allocated to the road have been reached in urban areas in some countries where data can be accessed. This study covered the three largest cities in Turkey; Istanbul, Ankara, Izmir and some other cities on which the surveyed. The main reason for this is that the urban population densities and zoning parameters of these cities may be misleading (Figure 3).

\section{Road Planning Criteria}

The road can be characterized as a strip or a network used to connect residential areas. One of the most important parameters of planning principles. The path field parameter, as shown in Figure 3 , is related to the amount of space to be allocated in the project area [4].

\section{International values for the road area}

The ratios of existing roads to urban area are shown in Table 1 on the basis of countries. The aforementioned ways are that which is intended; it is the sum of the transportation network of the major cities of the countries. In Denmark, the ratio of roads to urban areas is $22 \%$, while it is $16 \%$ in Australia and $15.5 \%$ in the United States [5-7]. In Denmark, this value is at the top of $22 \%$, while in Canada it is $10.6 \%$ and in Italy it is only $9.9 \%[6,8,9]$. The average of the percentage values for the countries in the table is calculated as $14.80 \%$. This ratio indicates an acceptable situation (Table 1).

Table 1: Data on road areas in some countries.

\begin{tabular}{|c|c|}
\hline Ratio to Country Urban Area & (\%) \\
\hline Australia & 16 \\
\hline US & 15.5 \\
\hline Denmark & 22 \\
\hline Italy & 9.9 \\
\hline Canada & 10.6 \\
\hline Average & 14.8 \\
\hline
\end{tabular}

\section{Road area percentage in turkey}

In the zoning plan reports prepared by the Bank of Provinces between the years of 2005-2013, the ratio of the average urban roads to urban areas for the settlements with a population of $100,000-499,999$ is as in Table 2 [10] (Table 2). According to the road area; while it is over $15 \%$ in relatively developed cities such as Denizli and İzmit, this rate is 7\% in developing cities in the east of the country such as Erzurum and Kars. In the final analysis; the average value of the road area in Turkey are found to be below the $10 \%$ range $[9,11]$. According to Polat $[12]$, the percentage of road area (\%) should not be less than $15 \%$ of the project area in order to ensure the application of developed countries, international standards and the level of human life. This value should find an area of application for new settlements and urban transformation projects. For example; considering a 5 hectare $\left(50,000 \mathrm{~m}^{2}\right)$ urban transformation project area, let us assume that the area divided into 6 and 8 meters of secondary roads is $4.000 \mathrm{~m}^{2}$ before the 
transformation implementation. This will disrupt urban traffic. The current road rate will be $8 \%$. This ratio is quite low. If a calculation is made for a minimum road rate of $15 \%$, the new road will be allocated $7.500 \mathrm{~m}^{2}$ (see Table 3) (Table 3).

Table 2: Distribution of road space in some cities of Turkey (\%).

\begin{tabular}{|c|c|}
\hline Region & Road Area (\%) \\
\hline Balıkesir & $8.00 \%$ \\
\hline Trabzon & $7.23 \%$ \\
\hline Erzurum & $7.50 \%$ \\
\hline İzmit & $16.15 \%$ \\
\hline Edirne & $8.30 \%$ \\
\hline Kütahya & $12.60 \%$ \\
\hline Aydin & $7.40 \%$ \\
\hline Erzincan & $9.20 \%$ \\
\hline Elâzı̆̆ & $9.90 \%$ \\
\hline Antakya & $6.40 \%$ \\
\hline Kars & $7.60 \%$ \\
\hline Denizli & $16.50 \%$ \\
\hline Average & $9.73 \%$ \\
\hline
\end{tabular}

Table 3: Road area calculation.

\begin{tabular}{|c|}
\hline Project Area $\left(\mathrm{m}^{2}\right) \times$ Road Area $(\%)=$ Road Area $\left(\mathrm{m}^{2}\right)$ \\
\hline $50000,00 \times 15,00 \%=7500,00$ \\
\hline
\end{tabular}

\section{Conclusion}

Implementation of an urban transformation requires extensive work within the framework of planning and zoning standards. It is considered that, instead of maintaining an individual building work in the current zoning conditions that are currently being implemented after the demolition - repair - renewal of the potential risky structures in the transformation areas, an urban area study should be conducted by evaluating the new planning chance. In the light of national and international criteria and recommendations, a regional-based planning study is believed to be the main nuance, rather than a disaster-driven urban transformation study. As a result, it is considered that the road parameter is of vital importance to share optimum areas in new settlements and to prevent distorted construction in urban transformation areas. An inland road transport network can be established with an accurate planning with active and efficient transportation axles. For this, a road space planning should be made in international standards. Compliance with urbanization criteria constitutes the main idea of improvement of zoning areas. Therefore, it should be noted that the area allocated to the road in a project area should not be below $15 \%$.

\section{Acknowledgment}

None.

\section{Conflict of Interest}

No conflict of interest.

\section{References}

1. Turkish Language Society, (2018) TDK Sözlüğü, Ankara.

2. Web, www.f5haber.com

3. Balyemez S, Berköz L (2005) Hasar Görebilirlik ve Kentsel Deprem Davranıșı. İTÜ dergisi/a, Mimarlık, Planlama, Tasarım 4(1):3-4.

4. Web, www.arkitera.com

5. Bartholomew H (1965) Land Uses in American Cities, Harvard University, Press, Cambridge, USA.

6. UN (1975) Urban Land Policies and Land-Use Control Measures, 7, Global Review, New York, USA.

7. Brown EJ (1969). An Introduction to Town and County Planning, Elsevier Publishing Company, New York, USA.

8. Cetiner A (1991) Șehircilik Calıșmalarında Donatım İlkeleri, Istanbul Technical University, Istanbul, Turkey.

9. National Swedish Board of Building and Planning (1965) Conference of the International Federation for Housing and planning, Stockholm.

10. Ministry of Environment and Urbanization of Turkey, (2013), A study on the urban settlements, Bank of Provinces.

11. Gürel S (1972) Türkiye'de Kent Mekânsal Standartları (Urban Spatial Standards in Turkey), TÜBİTAK Building Research Institute, Ankara.

12. Polat HI (2017) A Mathematical Model Suggestion for Urban Transformation in Turkey - Türkiye'de Kentsel Dönüš̈m Uygulamaları İçin Matematiksel Bir Model Önerisi, Ylldız Technical University, Institute of Science, Istanbul, Turkey. 